\title{
KARAKTERISASI SENSOR GAS LIQUEFIED PETROLEUM GAS (LPG) DARI BAHAN SEMIKONDUKTOR HETEROKONTAK CUO/CUO(TIO $\left.{ }_{2}\right)$
}

\author{
Essy Puspa Zelvia, Elvaswer \\ Jurusan Fisika FMIPA Universitas Andalas \\ Kampus Unand, Limau Manis, Padang, 25163 \\ e-mail: essypuspazelvia@yahoo.com
}

\begin{abstract}
ABSTRAK
Telah dilakukan karakterisasi sensor Liquefied Petroleum Gas (LPG) berupa pelet heterokontak dengan lapisan pertama pelet adalah $100 \%$ mol $\mathrm{CuO}$ dan lapisan kedua pelet adalah $\mathrm{CuO}$ yang dicampur $10 \% \mathrm{~mol}, 20 \% \mathrm{~mol}, 30 \% \mathrm{~mol}, 40 \% \mathrm{~mol}$ dan $50 \% \mathrm{~mol} \mathrm{TiO}_{2}$. Tahap pembuatan sensor LPG terdiri atas pencampuran bahan, kalsinasi pada temperatur $500^{\circ} \mathrm{C}$ selama 4 jam, penggerusan, kompaksi, dan sintering pada temperatur $700^{\circ} \mathrm{C}$ selama 4 jam. Sensor LPG diuji pada temperatur ruang $\left(27^{\circ} \mathrm{C}\right)$ dengan melihat karakteristik arus dan tegangan (I-V), nilai sensitivitas, nilai konduktivitas dan karakterisasi XRD. Karakteristik I-V menunjukkan perubahan terbesar terjadi pada sampel $\mathrm{CuO} / \mathrm{CuO}\left(20 \% \mathrm{~mol} \mathrm{TiO}_{2}\right)$. Nilai sensitivitas tertinggi dimiliki sampel $\mathrm{CuO} / \mathrm{CuO}(20 \%$ mol $\mathrm{TiO}_{2}$ ) sebesar 11,94 pada tegangan 10 volt, dan merupakan sampel yang paling bagus digunakan sebagai sensor gas LPG. Nilai konduktivitas tertinggi dimiliki sampel $\mathrm{CuO} / \mathrm{CuO}(10 \%$ mol $\mathrm{TiO}_{2}$ ) dengan nilai konduktivitas di udara sebesar $6,60557 \times 10^{-5} \Omega^{-1} \mathrm{~m}^{-1}$ dan nilai konduktivitas di LPG $25,80712 \times 10^{-5} \Omega^{-1} \mathrm{~m}^{-1}$.
\end{abstract}

Kata kunci : heterokontak, sensor LPG, $\mathrm{CuO} / \mathrm{CuO}\left(\mathrm{TiO}_{2}\right)$, karakterisasi I-V, sensitivitas, konduktivitas.

\begin{abstract}
The Liquefied Petroleum Gas (LPG's) sensor in the form of hetero-contact pellet has been characterized. The first layer of the sensor is pure $\mathrm{CuO}$ and the second is $\mathrm{CuO}$ mixed with $\mathrm{TiO}_{2}$ at various moles (10, 20, 30, 40 and 50\%). The steps of manufacturing processes are the mixing of materials, calcination at $500{ }^{\circ} \mathrm{C}$ for 4 hours, blending, compaction, and sintering at $700{ }^{\circ} \mathrm{C}$ for 4 hours. The sensor was tested at room temperature through current (I)-voltage (V) characteristics, sensitivity, conductivity and XRD observations. The most significant change of I-V characteristics was observed for the sample of $\mathrm{CuO} / \mathrm{CuO}\left(20 \%\right.$ mole of $\left.\mathrm{TiO}_{2}\right)$. The largest sensitivity of this sample is 11.94 at 10 Volt, and we concluded that this sample is the best to be used as the LPG's sensor. The sample of $\mathrm{CuO} / \mathrm{CuO}\left(10 \%\right.$ mole of $\left.\mathrm{TiO}_{2}\right)$ has the highest conductivity, i.e. 6.60557 $x 10^{-5} \Omega^{-1} m^{-1}$ and $25.80712 \times 10^{-5} \Omega^{-1} m^{-1}$ in air and the LPG respectively.
\end{abstract}

Keyword :LPG sensor, hetero-contact, $\mathrm{CuO} / \mathrm{CuO}\left(\mathrm{TiO}_{2}\right), \mathrm{I}-\mathrm{V}$ characteristic, sensitivity, conductivity

\section{PENDAHULUAN}

Liquefied Petroleum Gas (LPG) telah banyak digunakan mulai dari rumah tangga seperti pada kompor, penghangat ruangan hingga bahan bakar untuk menggerakkan mesin dalam 
industri. Banyaknya penggunaan gas LPG menyebabkan munculnya masalah yang selalu menjadi kendala dalam penggunaan gas ini, yaitu kebocoran dan ledakan gas. Jika gas LPG mengalami kebocoran akan tercium baunya sehingga kebocoran normal mudah dideteksi oleh pengguna secara subjektif. Akan tetapi, bila gas yang bocor meresap ke dalam saluran air, instalasi listrik, atau ke bawah karpet, maka akan sulit dideteksi oleh indra penciuman manusia. Terlebih lagi, keberadaan AC dan pemanas ruangan juga bisa menyamarkan bau gas yang seharusnya terdeteksi oleh hidung secara normal (Reyanda, dkk., 2013).

Resiko dibalik penggunaan gas LPG ini tentunya dapat diminimalisir dengan penggunaan alat yang mampu melakukan deteksi dini terhadap kebocoran gas. Alat ini bisa berupa perangkat keras, atau semacam sensor yang bisa bekerja efisien dengan sensitivitas yang tinggi terhadap kebocoran gas, salah satunya adalah sensor gas semikonduktor. Sensor dengan bahan semikonduktor memiliki kelebihan dalam mendeteksi gas, salah satunya dapat dilihat dari perubahan konduktivitas pada bahan material semikonduktor. Kelebihan lain dari sensor semikonduktor yaitu biaya bahan dan pembuatan yang murah dibandingkan dengan sensor gas elektrokimia dan optik (Hendri, 2012).

Bahan titanium dioxide $\left(\mathrm{TiO}_{2}\right)$ merupakan bahan semikonduktor metal oksida (metal oxide) dan memiliki beberapa kelebihan seperti harganya yang murah, mudah digunakan serta tidak mengandung racun. Kelebihan-kelebihan tersebut menjadikan $\mathrm{TiO}_{2}$ digunakan sebagai bahan dalam pembuatan sel surya, sensor kimia, evolusi gas hidrogen, dan untuk aplikasi pemurnian lingkungan misalnya air (Pookmanee dan Phanichphant, 2009).

Penelitian sensor gas LPG sebelumnya pernah dilakukan oleh Yadav dkk. (2010) dengan menggunakan bahan tunggal yaitu $\mathrm{TiO}_{2}$. Sensor LPG berupa pelet $\mathrm{TiO}_{2}$, diuji untuk mendeteksi LPG pada temperatur ruang. Kemudian, Hendri (2012) meneliti bahan $\mathrm{TiO}_{2}$ yang didoping dengan $\mathrm{CuO}$ sebagai sensor gas $\mathrm{CO}_{2}$. Penelitian ini menghasilkan sensor dengan nilai sensitivitas yang lebih tinggi pada bahan yang didoping dibandingkan bahan murni $\mathrm{TiO}_{2}$. Selanjutnya, Deswardani (2013) juga telah melakukan penelitian karakterisasi sensor gas LPG dengan menggunakan bahan $\mathrm{TiO}_{2}$ didoping oleh $\mathrm{ZnO}$. Hasil penelitian tersebut juga menunjukkan bahwa sensitivitas dan konduktivitas bahan yang didoping lebih tinggi dari bahan tanpa doping.

\section{METODE PENELITIAN}

\subsection{Persiapan Pembuatan Pelet $\mathrm{CuO}$ didoping $\mathrm{TiO}_{2}$}

Dalam penelitian ini diuji karakterisasi I-V dari semikonduktor heterokontak gas LPG. Sampel dibuat dengan lima macam persentase doping $\mathrm{TiO}_{2}$ yaitu sebanyak $10 \%, 20 \%, 30 \%$, 40\%, dan 50\% mol terhadap bahan dasar CuO. Berikut reaksi kimia yang terjadi pada pelet : 


$$
x \mathrm{CuO}+(1-x) \mathrm{TiO}_{2} \longrightarrow \mathrm{Cu}_{x} \mathrm{Ti}_{(1-x)} \mathrm{O}_{(2-x)}
$$

dengan $\mathrm{x}$ adalah jumlah doping yang ditambahkan dalam mol.

Bahan sampel digerus agar homogen selama 2 jam, kemudian dikalsinasi pada suhu $500^{\circ} \mathrm{C}$ selama 4 jam, kemudian bahan dikompaksi, setelah dikompaksi bahan disintering pada suhu $700^{\circ} \mathrm{C}$ selama 4 jam.

\subsection{Pengukuran Nilai I-V sensor LPG}

Untuk skema rangkaian alat penguji sensor LPG dapat dilihat pada Gambar 1.

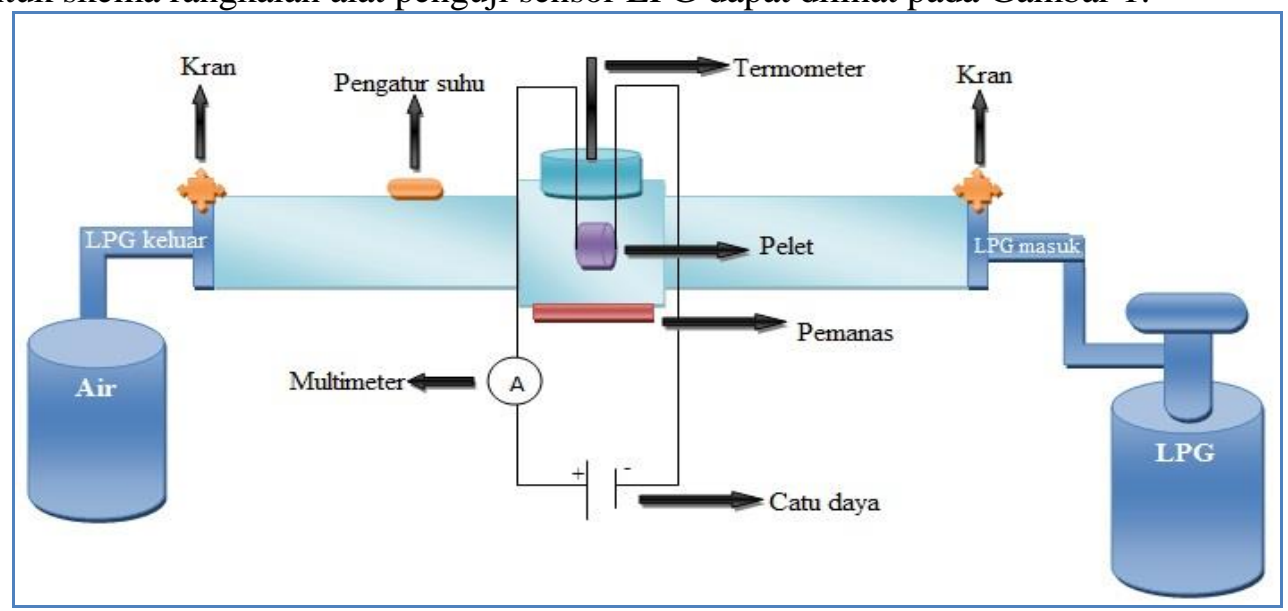

Gambar 1 Skema rangkaian alat pengujian sensor LPG

(Sumber: Basthoh, 2013)

Pengukuran nilai I-V dilakukan dengan salah satu bagian elektroda sampel dihubungkan dengan kutub positif sedangkan yang lainnya dihubungkan dengan kutub negatif (bias maju) dan untuk bias mundur polaritasnya dibalik. Antara sampel dan tegangan dihubungkan ke amperemeter, sehingga arus (I) dan tegangan (V) sampel dapat diukur. Pengukuran karakteristik I-V setiap sampel dilakukan dengan menyusun alat seperti Gambar 1. Temperatur yang digunakan adalah temperatur ruang, baik pada lingkungan udara maupun LPG. Pengukuran lebih dulu dilakukan pada lingkungan udara, kedua ujung pipa tidak dihubungkan dengan selang dan kran dibiarkan terbuka. Setelah semua persiapan dilakukan, sampel dirangkai bias maju dan kemudian dilanjutkan dengan bias balik. Tegangan divariasikan dari -30 Volt sampai dengan 30 Volt dengan interval 5 volt.

Pengukuran karakteristik I-V akan menentukan nilai sensitivitas sensor dan nilai konduktivitas sensor. Nilai sensitivitas dan konduktivitas dapat diketahui dengan melakukan perhitungan. Sensitivitas menunjukkan seberapa sensitif sensor dalam mendeteksi suatu zat. Nilai sensitivitas dapat ditentukan dengan Persamaan 1. 


$$
S=\frac{I_{\text {Udara }}}{I_{L P G}}
$$

dimana $\mathrm{S}$ adalah sensitivitas, Iudara adalah arus diudara sedangkan ILPG adalah arus disaat gas LPG dialirkan.

Konduktivitas menunjukkan kemampuan suatu bahan untuk mengalirkan arus listrik. Nilai konduktivitas dapat ditentukan dari Persamaan 2.

$$
\sigma=\frac{L}{R A}
$$

dimana, $\sigma$ adalah konduktivitas listrik (1/ $\Omega . \mathrm{m})$, R adalah resistansi $(\Omega)$, A adalah luas penampang $\left(\mathrm{m}^{2}\right)$, dan $\mathrm{L}$ adalah panjang sampel $(\mathrm{m})$.

\section{HASIL DAN DISKUSI}

\subsection{Karakteristik I-V sampel pada Lingkungan Udara dan LPG}

Karakteristik I-V pada lingkungan udara dan LPG dapat diamati dengan mengukur arus dan tegangan pada masing-masing lingkungan. Pengukuran arus dan tegangan dilakukan pada temperatur ruang $\left(30^{\circ} \mathrm{C}\right)$. Karakteristik $\mathrm{I}-\mathrm{V}$ untuk sampel pertama $\mathrm{CuO} / \mathrm{CuO}(50 \%$ mol $\left.\mathrm{TiO}_{2}\right)$ ditunjukkan pada Gambar 2, dan untuk sampel $\mathrm{CuO} / \mathrm{CuO}\left(40 \% \mathrm{~mol} \mathrm{TiO}_{2}\right)$, $\mathrm{CuO} / \mathrm{CuO}(30 \% \mathrm{~mol} \mathrm{TiO} 2), \mathrm{CuO} / \mathrm{CuO}(20 \% \mathrm{~mol} \mathrm{TiO} 2), \mathrm{CuO} / \mathrm{CuO}\left(10 \% \mathrm{~mol} \mathrm{TiO}_{2}\right)$, berturut-turut ditunjukkan pada Gambar 3, Gambar 4, Gambar 5, dan Gambar 6.

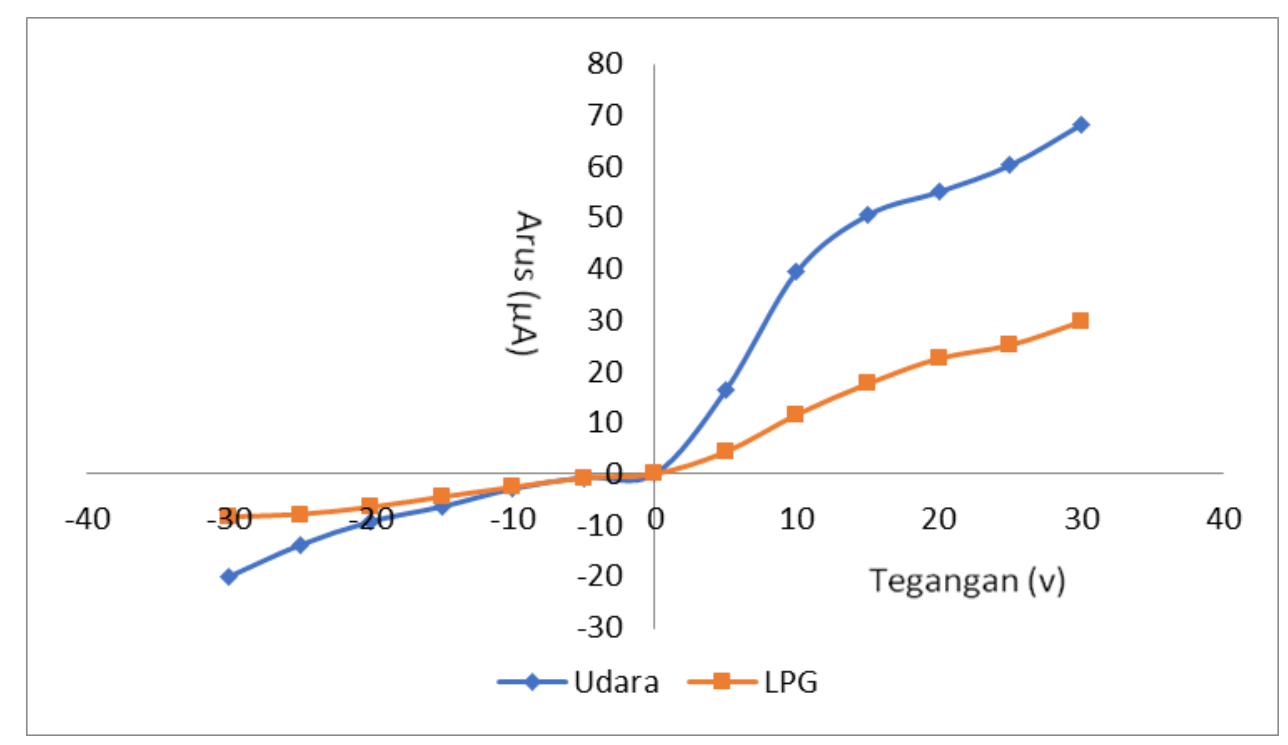

Gambar 2. Grafik I-V sampel $\mathrm{CuO} / \mathrm{CuO}\left(50 \% \mathrm{~mol} \mathrm{TiO}_{2}\right)$ 
Perbedaan arus pada lingkungan udara dan LPG menunjukkan bahwa arus pada lingkungan udara lebih besar dibandingkan arus pada lingkungan LPG. Dibandingkan bias mundur, arus pada bias balik nilainya lebih besar baik pada lingkungan udara maupun LPG. Hal ini dikarenakan sampel merupakan sampel heterokontak yang prinsip kerjanya sama dengan dioda $\mathrm{p}-\mathrm{n}$. Apabila sampel dibiaskan dalam arah maju, terjadi pengecilan daerah deplesi karena lubang-lubang sebagai pembawa muatan mayoritas pada tipe-p akan berpindah melalui sambungan ke tipe-n, sebaliknya elektron sebagai pembawa muatan mayoritas pada tipe-n akan berpindah melalui sambungan menuju tipep. Apabila sampel dibiaskan pada bias balik terjadi pelebaran daerah deplesi, karena baik elektron maupun lubang sebagai pembawa muatan mayoritas tertarik menjauhi sambungan. Sehingga arus pada bias maju lebih tinggi daripada arus pada bias balik.

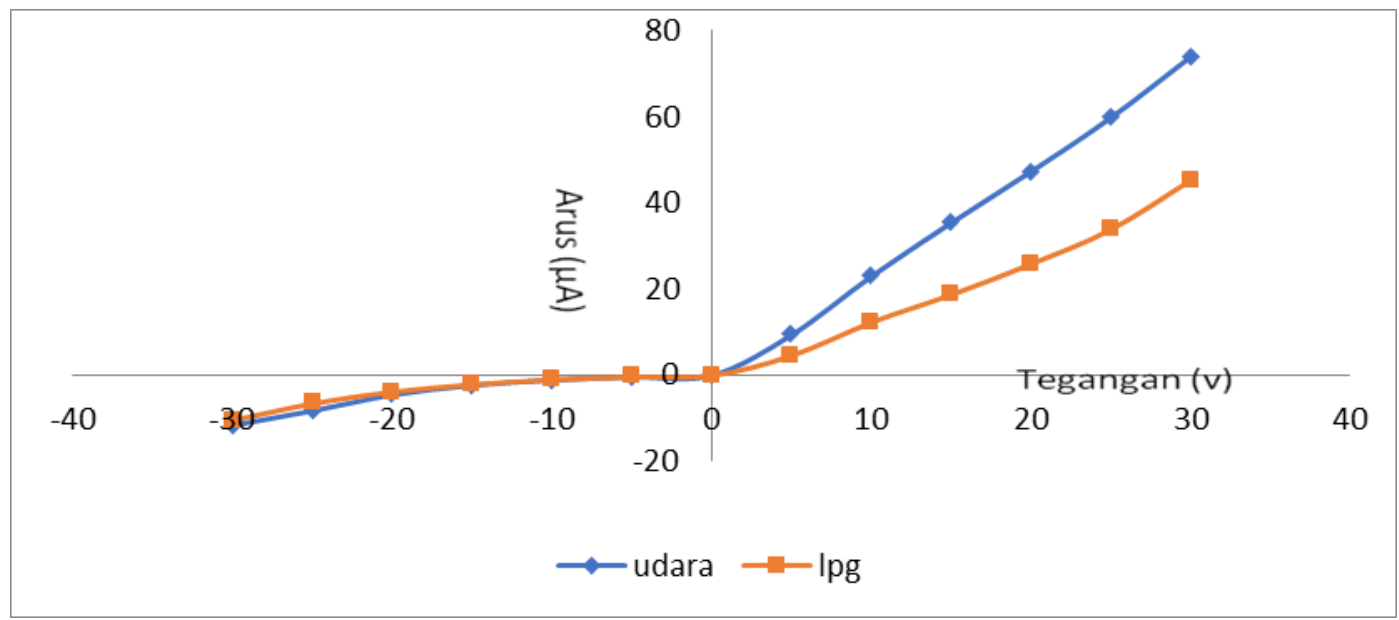

Gambar 3. Grafik I-V sampel $\mathrm{CuO} / \mathrm{CuO}\left(40 \% \mathrm{~mol} \mathrm{TiO}_{2}\right)$

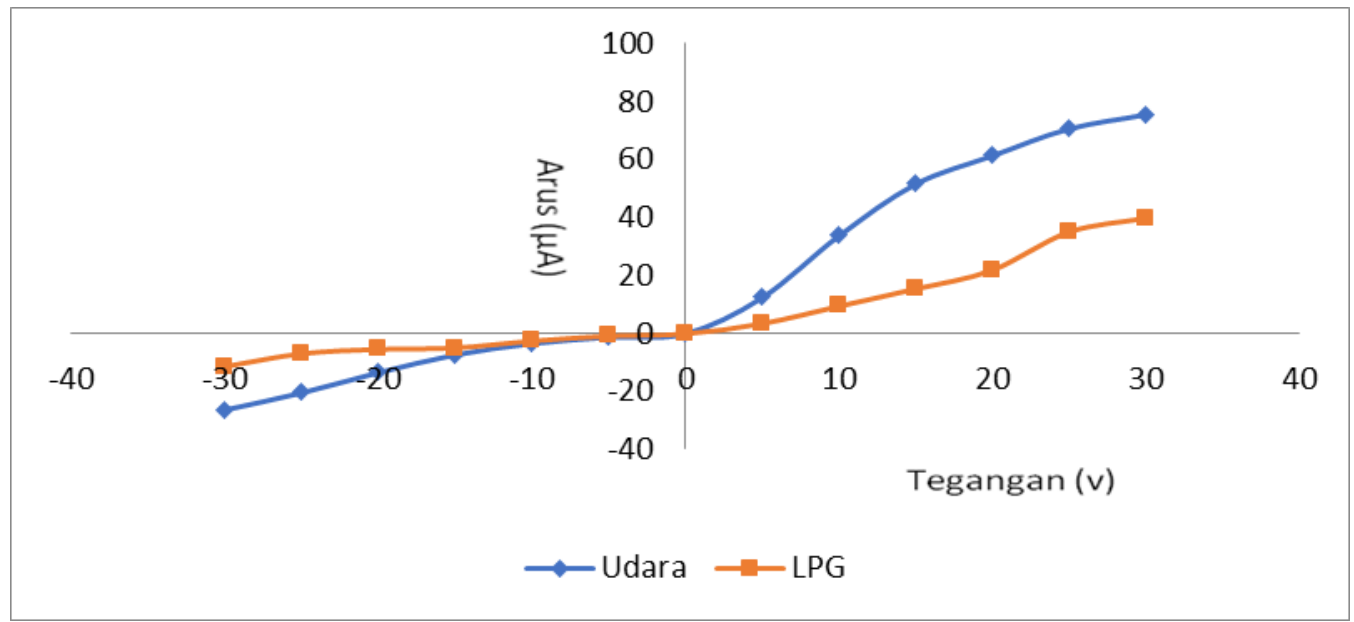

Gambar 4. Grafik I-V sampel $\mathrm{CuO} / \mathrm{CuO}\left(30 \% \mathrm{~mol} \mathrm{TiO}_{2}\right)$ 


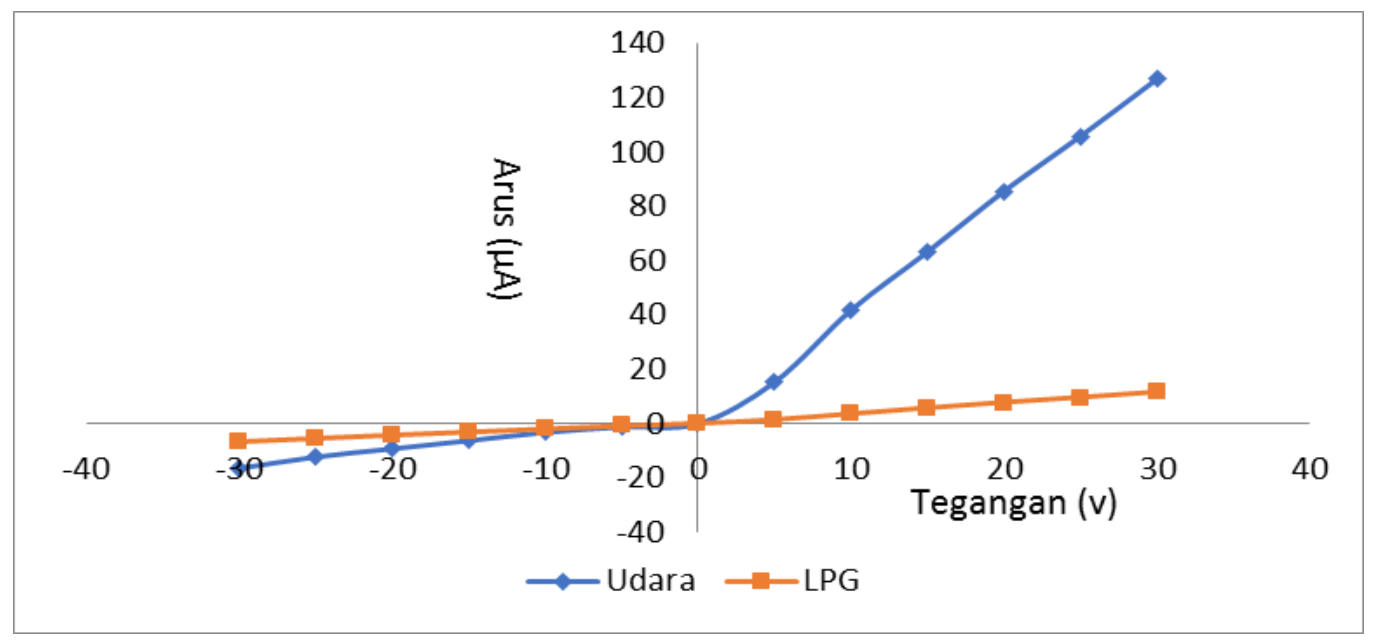

Gambar 5. Grafik I-V sampel $\mathrm{CuO} / \mathrm{CuO}\left(20 \% \mathrm{~mol} \mathrm{TiO}_{2}\right)$

Pada gambar 2 sampai 5 di atas menunjukkan arus pada lingkungan udara lebih tinggi dibandingkan arus pada lingkungan LPG. Ini disebabkan oleh adanya reaksi reduksi LPG dengan oksigen teradsorbsi pada sampel yang menyebabkan elektron sulit melewati celah energi sehingga arus yang mengalir pada sampel akan berkurang.

Lapisan pertama sampel adalah $\mathrm{CuO}$ yang merupakan semikonduktor tipe-p. Sedangkan lapisan kedua sampel adalah komposit $\mathrm{CuO}\left(\mathrm{TiO}_{2}\right)$. Pada keempat sampel yang berfungsi sebagai material pengotor adalah $\mathrm{CuO}$ yang memiliki dua elektron valensi, sehingga ketika material pengotor ini diberikan kepada $\mathrm{TiO}_{2}$ yang memiliki empat elektron valensi maka akan terbentuk senyawa dengan kelebihan dua lubang, sehingga lapisan kedua pada sampel merupakan semikonduktor tipe-p.

Menurut Nopriyanti (2012), untuk semikonduktor tipe-p nilai resistansi arus menurun ketika bereaksi dengan gas pereduksi seperti LPG. Sehingga ketika sampel berada pada lingkungan LPG, gas LPG akan bereaksi reduksi dengan oksigen teradsorbsi pada sampel dan menghasilkan arus yang lebih rendah dibandingan arus pada lingkungan udara. 


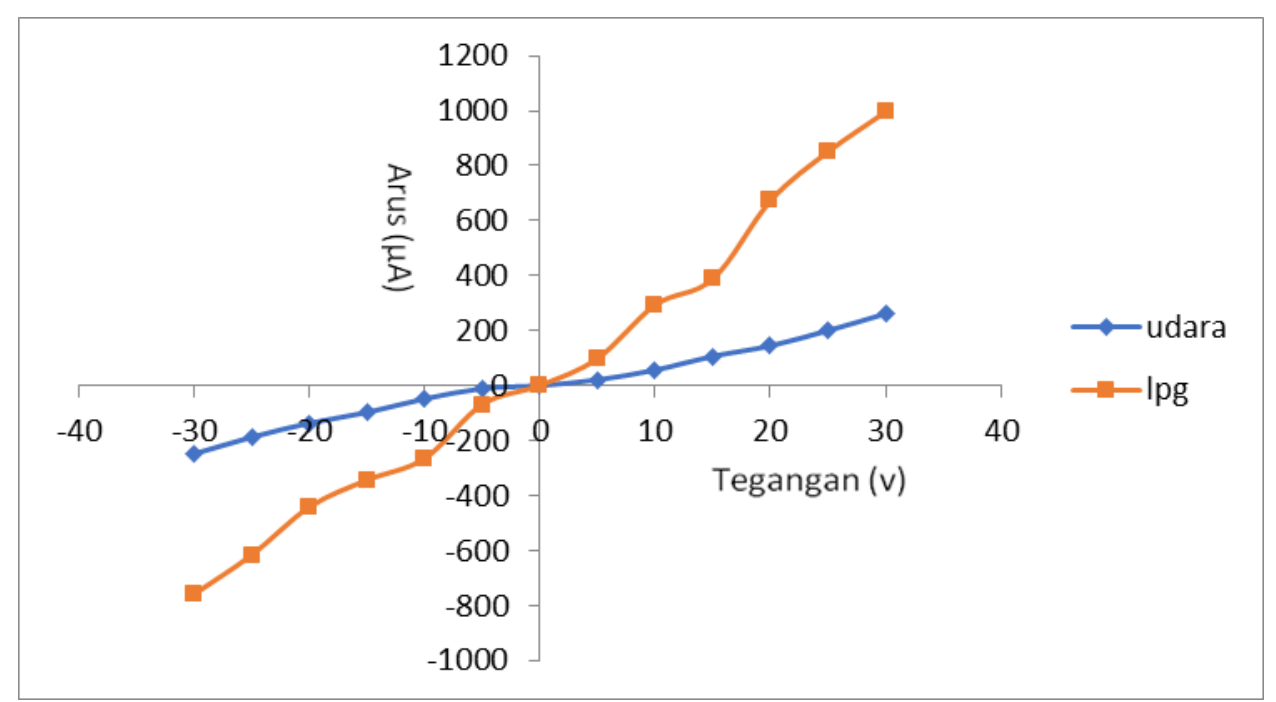

Gambar 6. Grafik I-V sampel $\mathrm{CuO} / \mathrm{CuO}\left(10 \% \mathrm{~mol} \mathrm{TiO}_{2}\right)$

Berbeda dari empat sampel sebelumnya grafik sampel $\mathrm{CuO} / \mathrm{Cu} 0\left(10 \% \mathrm{~mol} \mathrm{TiO}_{2}\right)$ menunjukkan arus pada lingkungan LPG lebih tinggi dibandingkan arus pada lingkungan udara. Ini disebabkan karena penambahan doping $\mathrm{TiO}_{2}$ terhadap $\mathrm{CuO}$ pada lapisan kedua sampel paling kecil diantara sampel lainnya yaitu $10 \% \mathrm{~mol} \mathrm{TiO}_{2}$, sehingga kemungkinan adanya cacat kristal kecil. Cacat kristal pada material zat padat memiliki pengaruh terhadap sifat fisisnya, salah satunya pada sifat listrik seperti perubahan arus listrik yang signifikan, perubahan tegangan, hambatan ataupun kapasitansi (Solikha, 2011). Cacat kristal pada sampel $\mathrm{CuO} / \mathrm{CuO}\left(10 \% \mathrm{~mol} \mathrm{TiO}_{2}\right)$ mengakibatka nilai arus pada lingkungan LPG lebih tinggi daripada nilai arus pada lingkungan udara.

Variabel lain yang mempengaruhi nilai arus pada LPG, lebih tinggi daripada lingkungan udara pada sampel $\mathrm{CuO} / \mathrm{CuO}\left(10 \% \mathrm{~mol} \mathrm{TiO}_{2}\right)$ adalah permukaan sensor akan menyerap molekul-molekul oksigen yang berada di udara. Molekul-molekul oksigen yang teradsorbsi ini akan mengikat elektron bebas pada permukaan bahan sensor semikonduktor. Pengikatan elektron bebas menyebabkan terbentuknya lapisan deplesi (daerah kosong muatan bebas) pada daerah antara gas dan butir kristal. Pembentukan lapisan deplesi disertai pula dengan pembentukan potensial penghalang (potensial barrier) didaerah batas butir. Pembentukan lapisan deplesi dan potensial penghalang akan menentukan sifat kelistrikan sensor semikonduktor (Sayono, dkk., 2008). Ketika diberikan gas LPG lapisan deplesi akan mengecil, sehingga elektron akan mudah berpindah ke pita konduksi sehingga menyebabkan potensial penghalang menurun, dengan begitu arus pada LPG akan meningkat.

\subsection{Karakteristik Sensitivitas}

Sensitivitas sensor LPG dari bahan semikonduktor heterokontak $\mathrm{CuO} / \mathrm{TiO}_{2}(\mathrm{CuO})$ dapat diketahui berdasarkan karakteristik I-V yang telah diperoleh. Perubahan sensitivitas kelima sampel dapat dilihat pada Gambar 7. 


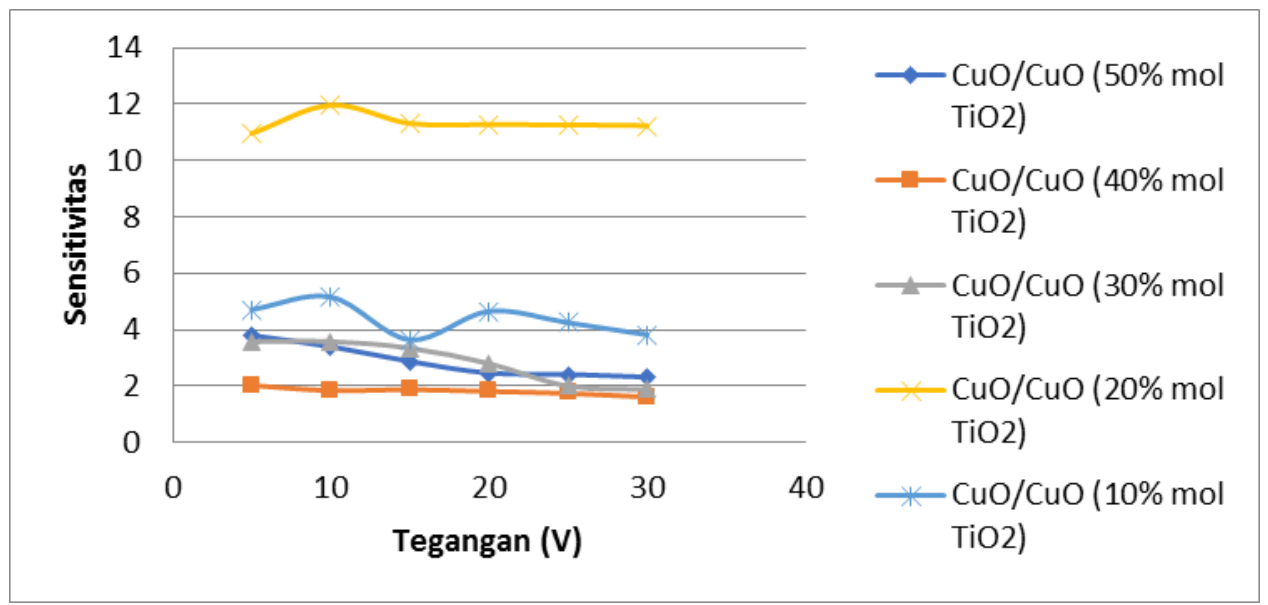

Gambar 7. Grafik perubahan sensitivitas terhadap tegangan

Berdasarkan gambar dapat diketahui bahwa sampel yang memiliki sensitivitas terbesar adalah sampel $\mathrm{CuO} / \mathrm{CuO}\left(20 \% \mathrm{~mol} \mathrm{TiO}_{2}\right)$, sedangkan sensitivitas yang paling kecil adalah sampel $\mathrm{CuO} / \mathrm{CuO}\left(40 \% \mathrm{~mol} \mathrm{TiO}_{2}\right)$. Hal ini karena keempat sampel ini didominasi dengan semikonduktor tipe-p. Bahan dengan kelebihan lubang akan bereaksi reduksi terhadap LPG sehingga terjadi penurunan arus. Begitupun dengan sampel $\mathrm{CuO} / \mathrm{CuO}$ $\left(10 \%\right.$ mol $\left.\mathrm{TiO}_{2}\right)$ karena adanya cacat kristal ketika sampel bereaksi dengan gas LPG terjadi kenaikan arus yang signifikan. Perubahan nilai arus inilah yang mempengaruhi nilai sensitivitas sensor LPG.

\subsection{Nilai Konduktivitas Sampel di Lingkungan Udara dan LPG}

Perubahan konduktivitas pada lingkungan udara yang ditunjukkan pada Gambar 8 .

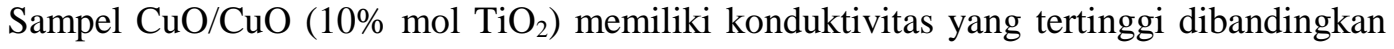
sampel-sampel lainnya. Setelah diberikan pengaruh LPG yang dapat dilihat pada Gambar 9 bahwa sampel $\mathrm{CuO} / \mathrm{CuO}\left(50 \%\right.$ mol $\left.\mathrm{TiO}_{2}\right)$, sampel $\mathrm{CuO} / \mathrm{CuO}\left(40 \% \mathrm{~mol} \mathrm{TiO}_{2}\right)$, sampel $\mathrm{CuO} / \mathrm{CuO}\left(30 \% \mathrm{~mol} \mathrm{TiO}_{2}\right)$ dan sampel $\mathrm{CuO} / \mathrm{CuO}\left(20 \% \mathrm{~mol} \mathrm{TiO}_{2}\right)$ pada lingkungan LPG lebih rendah dibandingan lingkungan udara. Karena ketika berekasi dengan gas LPG hambatan akan meningkat sehingga arus pada lingkungan LPG mengalami penurunan. Sebaliknya pada $\mathrm{CuO} / \mathrm{CuO}\left(10 \% \mathrm{~mol} \mathrm{TiO}_{2}\right)$ nilai konduktivitas pada lingkungan LPG jauh lebih tinggi dibandingakn konduktivitas pada lingkungan udara. Karena ketika berekasi dengan gas LPG hambatan menurun sehingga arus pada lingkungan LPG mengalami kenaikan. 


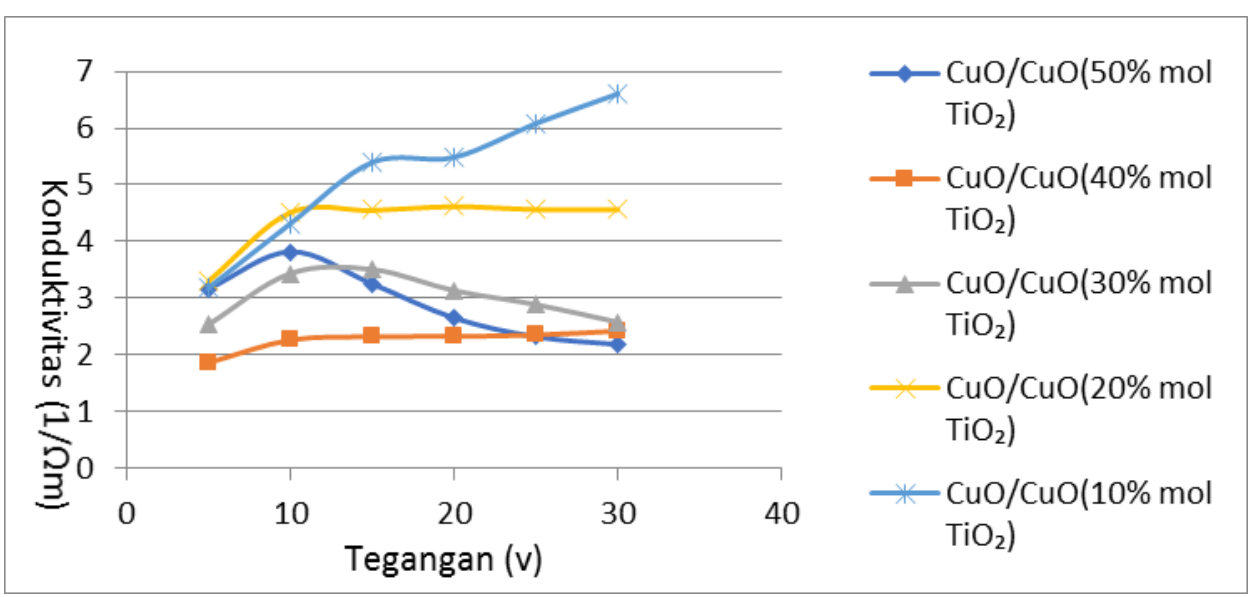

Gambar 8. Grafik perubahan konduktivitas di lingkungan udara

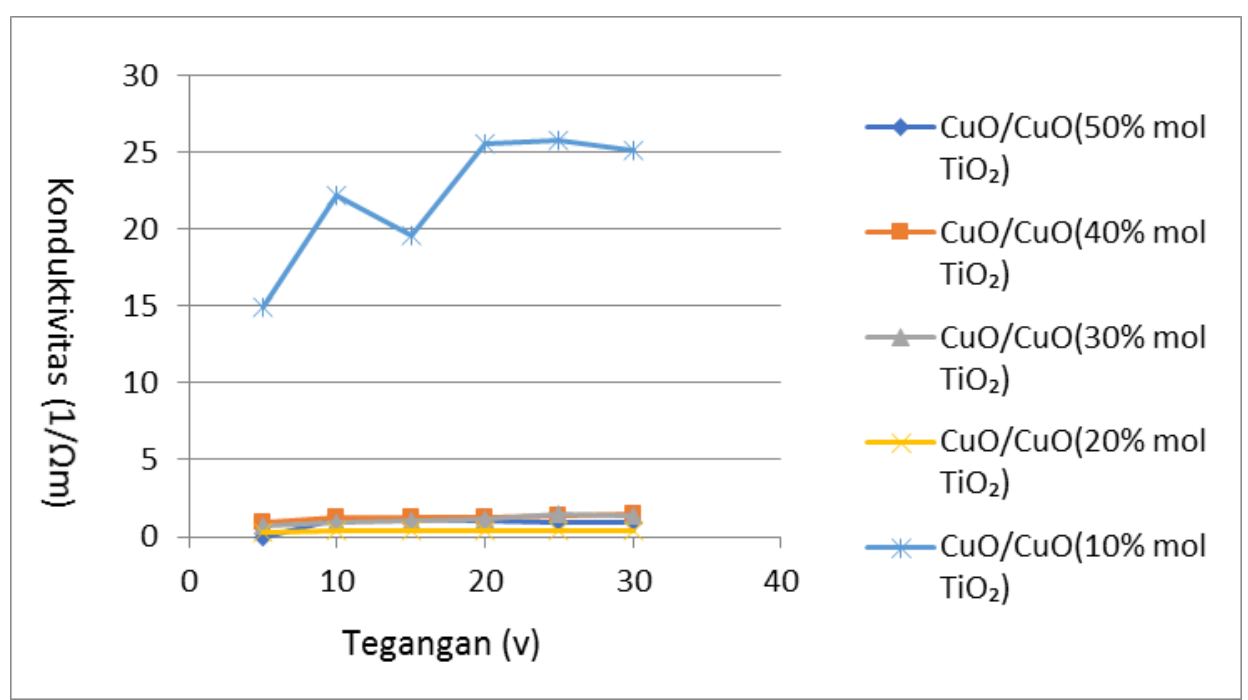

Gambar 9. Grafik perubahan konduktivitas di lingkungan LPG

\section{KESIMPULAN}

Berdasarkan hasil penelitian ini dapat disimpulkan bahwa sensor sudah mampu membedakan kondisi lingkungan udara dengan lingkungan LPG. Nilai sensitivitas tertinggi terdapat pada sampel $\mathrm{CuO} / \mathrm{CuO}\left(20 \% \mathrm{~mol} \mathrm{TiO}_{2}\right)$ yaitu 11,94 , sehingga sampel ini merupakan sampel yang paling baik digunakan sebagai sensor gas LPG. Konduktivitas pada lingkungan LPG lebih tinggi dibandingkan pada lingkungan udara. Konduktivitas tertinggi dimiliki oleh sampel $\mathrm{CuO} / \mathrm{CuO}\left(10 \%\right.$ mol $\left.\mathrm{TiO}_{2}\right)$ dengan sensitivitas pada udara yaitu $6,60557 \times 10^{-5} \Omega^{-1} \mathrm{~m}^{-1}$ dan nilai konduktivitas di LPG $25,80712 \times 10^{-5} \Omega^{-1} \mathrm{~m}^{-1}$. 


\section{DAFTAR PUSTAKA}

1. Basthoh, E., 2013, Karakterisasi ZnO Didoping $\mathrm{TiO}_{2}$ untuk Detektor LPG, Tesis, Program Studi S-2 Fisika, Fakultas Matematika dan Ilmu Pengetahuan Alam, Universitas Andalas, Padang

2. Deswardani, F., 2013, Karakterisasi Semikonduktor $\mathrm{TiO}_{2}(\mathrm{ZnO})$ Sebagai Sensor Liquefied Petroleum Gas (LPG), Skripsi, Program Studi S-1 Fisika, Fakultas Matematika dan Ilmu Pengetahuan Alam, Universitas Andalas, Padang.

3. Hendri, 2012, Karakterisasi $\mathrm{TiO}_{2}(\mathrm{CuO})$ dengan Metoda Keadaan Padat (Solid State Reaction) sebagai Sensor Gas $\mathrm{CO}_{2}$, Skripsi, Program Strudi S-1 Fisika, Fakultas Matematika dan Ilmu Pengetahuan Alam, Universitas Andalas, Padang.

4. Nopriyanti, R., 2012, Sintesis Lapisan Tipis $\mathrm{SnO}_{2}$ dalam Aplikasinya sebagai Sensor Gas CO dan Pengujian Sensitivitas, Universitas Pendidikan Indonesia, Bandung.

5. Pookmanee, P. dan Phanichpant, S., 2009, Titanium Dioxide Powder Prepared by a Sol-Gel Method, Jurnal, Vol.10 No.2, pp 167-170 , Jur. Kimia Universitas Chiang Mai, Thailand.

6. Reyanda, D., Maulana, O.P. dan Ramdan, R.A., 2013, Alat Pendetekdi Gas LPG Dengan Sensor TGS 2610 Berbasis Mikrokontroler ATmega 8535, Jurnal, Vol. 098 hal. 11-19, Jur. Elektro Universitas Negeri Jakarta.

7. Sayono., Sujitno, Tjipto. Dan Susita, Lely., 2008, Efek Doping Indium Terhadap Sensitivitas Sensor Gas ZnO, Jurnal, Vol 10 ISSN 1411-1349, P3TM - BATAN.

8. Solikha,W., 2011, Pembuatan Sensor Gas Etanol Keramik $\mathrm{Fe}_{2} \mathrm{O}_{3}$ yang didoping $10 \%$ mol CuO dengan Menggunakan Metode Screen Printing, Skripsi, Program Studi S-1 Fisika, Fakultas Pendidikan Matematika dan Ilmu Pengetahuan Alam, Universitas Pendidikan Indonesia, Bandung.

9. Yadav, B. C., 2011, Solid-state Titania-based Gas Sensor for Liquefied Petroleum Gas Detection at Room Temperature, Bull. Mater. Sci., Jurnal, Vol. 34, No. 7, hal. 1639-1644. 